\title{
DURA A DITA DEMOCRACIA
}

\section{HARSH DEMOCRACY}

Ariana da Rosa Silva ${ }^{1}$

Abri os olhos e acordei.

Eu sonhava! Ou pesadelo?

O que ouvi:

Um desespero.

Então os gritos

Ressoavam

Os manifestos

Ecoavam.

Das ruas da cidade:

Ele não

Pode estar

Falando a verdade.

Ainda estava por vir

Uma triste realidade

O ódio e a ignorância

No lugar da sanidade.

\footnotetext{
${ }^{1}$ Atualmente é Doutoranda em Estudos de Linguagem na Universidade Federal Fluminense - UFF. Mestra em Estudos de Linguagem pela mesma instituição. e-mail: arianarosa86@gmail.com
} 
Revista

Debates Insubmissos

De um lado, o fascismo.

De outro, a resistência.

Mas a gente não sabia

Qual grito persistiria...

Racismo, intolerância e violência...

Machismo, arrogância e desavença...

O grito da luta

Só aumentava

Mas o opressor não se calava...

Famílias inteiras se desentendiam...

E as amizades se desfaziam...

Duros momentos do início

De uma dita... democracia...

E a gente não sabia

Qual grito resistiria...

Submetido em: 17/10/2019

Aprovado em: 03/03/2020 